\title{
Mast Cell Tryptase Regulates Rat Colonic Myocytes Through Proteinase-activated Receptor 2
}

\author{
Carlos U. Corvera, ${ }^{*}$ Olivier Déry, ${ }^{*}$ K. McConalogue, ${ }^{*}$ Stephan K. Böhm, ${ }^{*}$ Lev M. Khitin, ${ }^{*}$ George H. Caughey, ${ }^{\# \mid}$ \\ Donald G. Payan, ${ }^{\ddagger}$ and Nigel W. Bunnett ${ }^{\star \S}$ \\ $*$ Department of Surgery, ${ }^{\ddagger}$ Department of Medicine, ${ }^{\S}$ Department of Physiology, and the ${ }^{\|}$Cardiovascular Research Institute, University of \\ California, San Francisco, San Francisco, California 94143-0660
}

\begin{abstract}
Proteinase-activated receptor-2 (PAR-2) is a G protein-coupled receptor that is cleaved and activated by trypsin-like enzymes. PAR-2 is highly expressed by small intestinal enterocytes where it is activated by luminal trypsin. The location, mechanism of activation, and biological functions of PAR-2 in the colon, however, are unknown. We localized PAR-2 to the muscularis externa of the rat colon by immunofluorescence. Myocytes in primary culture also expressed PAR-2, assessed by immunofluorescence and RT-PCR. Trypsin, SLIGRL-NH ${ }_{2}$ (corresponding to the PAR-2 tethered ligand), mast cell tryptase, and a filtrate of degranulated mast cells stimulated a prompt increase in $\left[\mathrm{Ca}^{2+}\right]_{i}$ in myocytes. The response to tryptase and the mast cell filtrate was inhibited by the tryptase inhibitor BABIM, and abolished by desensitization of PAR-2 with trypsin. PAR-2 activation inhibited the amplitude of rhythmic contractions of strips of rat colon. This response was unaffected by indomethacin, $\mathrm{L}-\mathrm{N}^{\mathrm{G}}$-nitroarginine methyl ester, a bradykinin $B_{2}$ receptor antagonist and tetrodotoxin. Thus, PAR-2 is highly expressed by colonic myocytes where it may be cleaved and activated by mast cell tryptase. This may contribute to motility disturbances of the colon during conditions associated with mast cell degranulation. (J. Clin. Invest. 1997. 100: 1383-1393.) Key words: trypsin - ileus - inflammation • smooth muscle
\end{abstract}

\section{Introduction}

Certain proteases specifically regulate cells by cleaving members of a new family of proteinase-activated receptors (PARs). PAR-1 and PAR-3, which are thrombin receptors, and PAR-2, a trypsin receptor, are the three known members of this family of $\mathrm{G}$ protein-coupled receptors (1-3). Thrombin and trypsin

Address correspondence to Nigel Bunnett, Box 0660, University of California, San Francisco, 521 Parnassus Avenue, San Francisco, CA 94143-0660. Phone: 415-476-0489; FAX: 415-476-0936; E-mail: nigelb@ itsa.ucsf.edu

Received for publication 13 March 1997 and accepted in revised form 24 June 1997.

1. Abbreviations used in this paper: AP, activating peptide SLIGRL$\mathrm{NH}_{2}$; BABIM, bis(5-amidino-2-benzimidazolyl)methane; L-NAME, $\mathrm{L}-N^{\mathrm{G}}$-nitroarginine methyl ester; PAR, proteinase-activated receptor; $\mathrm{RP}$, reverse peptide LRGILS-NH .

J. Clin. Invest.

(C) The American Society for Clinical Investigation, Inc. 0021-9738/97/09/1383/11 \$2.00

Volume 100, Number 6, September 1997, 1383-1393

http://www.jci.org cleave within the extracellular $\mathrm{NH}_{2}$ terminus of PAR-1 and PAR-2, respectively, to expose tethered ligands that bind to and thereby activate the cleaved receptors. Synthetic peptides corresponding to the tethered ligands directly bind and activate the receptors, and are valuable reagents to investigate receptor functions $(1,3)$.

PAR-1 is expressed by platelets, endothelial cells, fibroblasts, and astrocytes where it mediates many of the biological actions of thrombin (4). PAR-2 is expressed in the gastrointestinal tract, pancreas, kidney, liver, airway, prostate, ovary, and eye, and is found in enterocytes, keratinocytes, endothelial cells, smooth muscle, $\mathrm{T}$ cell lines, and certain tumor cell lines (3, 5-12). The proteases that cleave and activate PAR-2 in these multiple locations and the physiological role of PAR-2 are unknown. Pancreatic trypsin may cleave and activate PAR-2 in some tissues. For example, trypsin activates PAR-2 at the apical membrane of enterocytes, and thereby regulates the intestinal mucosa (13). Other trypsin-like proteases may activate PAR-2 in tissues that are not normally exposed to pancreatic trypsin. One possibility is mast cell tryptase, a prominent serine protease that is present in secretory granules of human mast cells (14). Tryptase is mitogenic for epithelial cells, fibroblasts, and smooth muscle cells, and stimulates ICAM expression by epithelial cells, but the receptor that mediates these actions is unknown (15-18). Mast cell tryptase has trypsin-like specificity, and cleaves and activates PAR-2 (19) (Böhm et al., manuscript submitted for publication). Thus, tryptase may activate PAR-2 in multiple locations when mast cells degranulate.

The purpose of this investigation was to define mechanisms of activation and the possible function of PAR-2 in the colon. Although PAR-2 mRNA is highly expressed in the colon (3, 6), its cellular location, mechanism of activation, and biological functions are unknown. Mast cells are normally present in the colon (20), and intestinal manipulation and inflammation result in mast cell infiltration, degranulation, and tryptase release (21-23). Tryptase may activate PAR-2 and thereby contribute to functional disturbances that accompany mast cell infiltration and degranulation in the colon. We found that PAR-2 is highly expressed in colonic muscle, and we examined the hypothesis that mast cell tryptase cleaves and activates PAR-2 on colonic myocytes, and thereby regulates colonic motility. The aims were $(a)$ to localize PAR-2 to colonic muscle; $(b)$ to determine if trypsin and mast cell tryptase activate PAR-2 in myocytes; and (c) to evaluate the role of PAR-2 in regulating colonic motility.

\section{Methods}

Reagents. Trypsin was from Worthington Biochemical Corp. (Freehold, NJ). Tryptase was extracted and purified from the human HMC-1 mast cell line (Dr. J. Butterfield, Mayo Clinic, Rochester, MN) by variations of previously described techniques $(18,24)$. High-ionic 
strength extracts of cells (in buffer containing $2 \mathrm{M} \mathrm{NaCl}$ and $10 \mathrm{mM}$ bis-Tris, $\mathrm{pH}$ 6.1) were applied to a column of benzamidine Sepharose (Sigma Chemical Co., St. Louis, MO), and eluted from the column in the same buffer containing $150 \mathrm{mM}$ benzamidine. The eluate was applied to a column of PD-10 (Pharmacia LKB Biotechnology Inc., Piscataway, $\mathrm{NJ}$ ) to remove benzamidine and to reduce the concentration of $\mathrm{NaCl}$ to $0.2 \mathrm{M}$. The desalted eluate was loaded immediately onto a Mono S column (Pharmacia LKB Biotechnology Inc.) and eluted with a linear gradient of $0-200 \mu \mathrm{g} / \mathrm{ml}$ bovine lung heparin (Sigma Chemical Co.).The tryptase inhibitor bis(5-amidino-2-benzimidazolyl)methane (BABIM) was from Dr. R. Tidwell, University of North Carolina (25). The tethered ligand of rat PAR-2 (activating peptide, AP; SLIGRL-NH ${ }_{2}$ ) and the reverse peptide (RP; LRGILS-NH $\mathrm{N}_{2}$ ) were synthesized by solid phase methods. Fura-2/AM was from Molecular Probes, Inc. (Eugene, OR). Bradykinin was from Bachem Bioscience Inc. (King of Prussia, PA). The bradykinin B2 receptor antagonist HOE 140 was from Dr. K. Wirth (Hoechst, Frankfurt, Germany). $\mathrm{PGE}_{2}$ was from DuPont-NEN (Boston, MA). An antibody to smooth muscle actin was from Enzo Diagnostics (Long Island, NY). Goat anti-rabbit IgG conjugated to fluorescein or Texas Red were from
Organon Teknika-Cappel (Durham, NC). Other reagents were from Sigma Chemical Co. Tissues were obtained from male Sprague-Dawley rats $(200 \mathrm{~g})$ anesthetized with $50 \mathrm{mg} / \mathrm{kg}$ i.p. sodium pentobarbital.

Isolation and culture of colonic myocytes. Myocytes were isolated from the muscularis externa of the rat colon as described (26), with the exception that tissue was placed in isolation buffer containing 50 $\mu \mathrm{g} / \mathrm{ml}$ fungizone, $1,000 \mathrm{U} / \mathrm{ml}$ penicillin, $1,000 \mu \mathrm{g} / \mathrm{ml}$ streptomycin, so that cells could be cultured. Dispersed cells were suspended in Smooth Muscle Basal Medium (Clonetics, San Diego, CA) containing $5 \% \mathrm{FCS}$ and $50 \mu \mathrm{g} / \mathrm{ml}$ gentamicin sulphate, plated onto plastic plates coated with rat tail collagen, and maintained in $95 \%$ air, $5 \%$ $\mathrm{CO}_{2}$ at $37^{\circ} \mathrm{C}$. After overnight culture, nonadherent myocytes were removed by changing the medium. Myocytes were studied between passages $2-5$, and were plated $48 \mathrm{~h}$ before use.

Localization of PAR-2 in tissue sections and cultured myocytes. Rats were transcardially perfused with $4 \%$ paraformaldehyde in 100 $\mathrm{mM}$ PBS, $\mathrm{pH} 7.4$, and $10-\mu \mathrm{m}$ frozen sections were prepared. Colonic myocytes were fixed in $4 \%$ paraformaldehyde for $20 \mathrm{~min}$ at $4^{\circ} \mathrm{C}$. PAR-2 was localized by indirect immunofluorescence, as described (27), using polyclonal antisera raised in rabbits to synthetic fragments of PAR-2
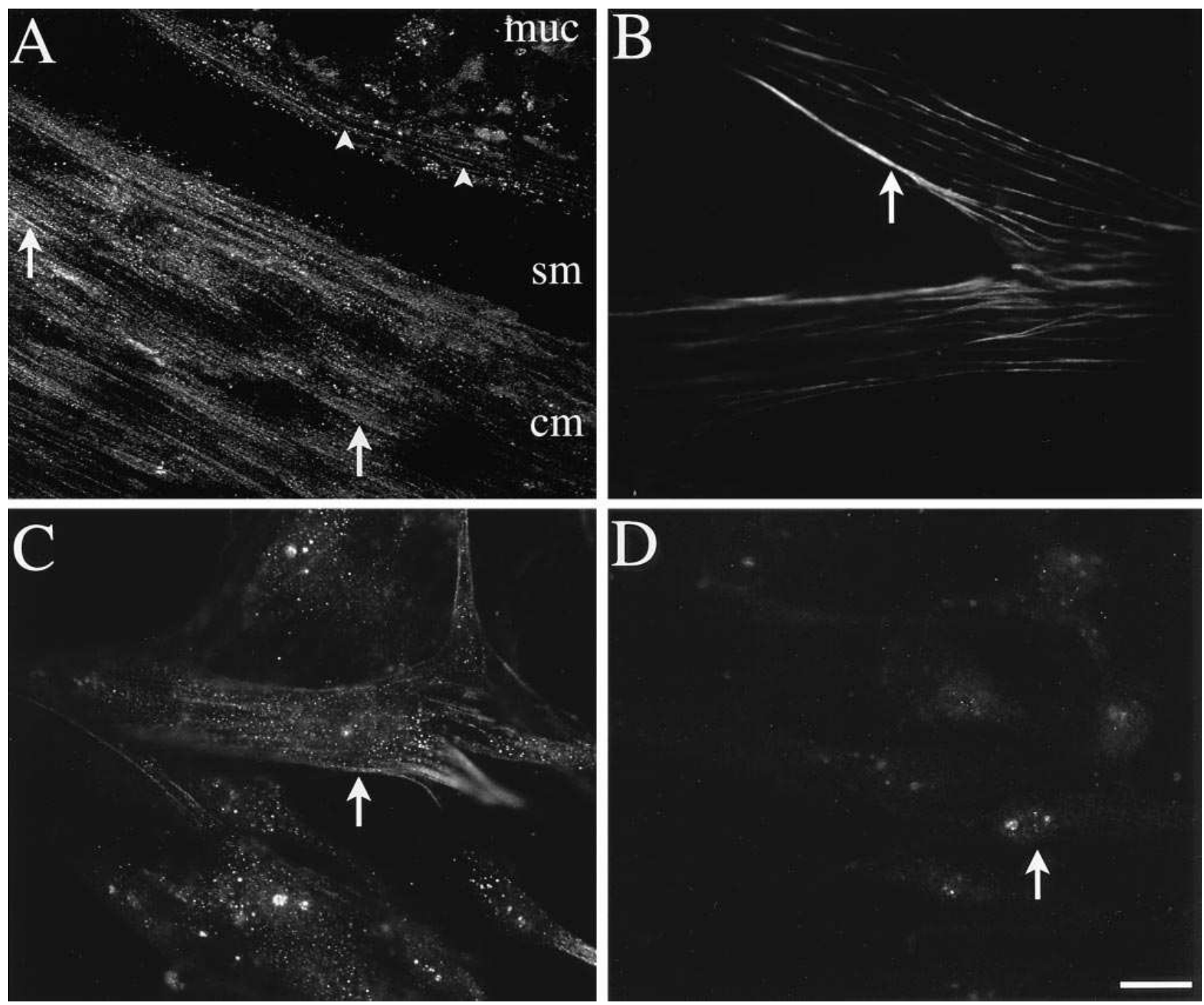

Figure 1. Localization of PAR-2 immunoreactivity in myocytes of the rat colon. $A$ is a section of rat colon showing PAR-2 in the muscularis mucosa (arrowheads) and muscularis externa (arrows) stained with antibody B5. muc, mucosa; sm, submucosa; cm, circular muscle. $B-D$ show isolated myocytes stained with an antibody to smooth muscle actin $(B)$, PAR-2-N antibody $(C)$, and PAR-2-N antibody preabsorbed with the receptor fragment used for immunization $(D)$. Scale bar $=10 \mu \mathrm{m}$. 
coupled to keyhole limpet hemocyanin. Antiserum B5 (Dr. M. Hollenberg, University of Calgary) was raised to rat PAR-2: ${ }^{30}$ GPNSKGR $\downarrow$ SLIGRLDT ${ }^{46} \mathrm{P}-$ YGGC $(\downarrow$ trypsin cleavage site, YGGC for conjugation) (13). Antiserum PAR-2-C was raised to human PAR-2: $\downarrow$ ${ }^{37}$ SLIGKVDGTSHVTGKG ${ }^{53} \mathrm{~V}$, and antiserum PAR-2-N was raised to human PAR-2: ${ }^{28}$ GTNRSSKGR $\downarrow$ SL ${ }^{39}$ I (Dr. C. Derian, R.W. Johnson Pharmaceutical Research Institute, Spring House PA).

Detection of PAR-2 in myocytes by RT-PCR and Southern blotting. Total RNA was reverse-transcribed and amplified using the GeneAmp RNA PCR kit (Perkin Elmer Cetus Instruments, Emeryville, CA). Oligonucleotide primers to rat PAR-2 (sense, 5'-AAGTCTCAGCCTGGCGTGGC-3', +6 to +25; antisense, 5' -ACGACGAGCAGCACGTTGCT- $3^{\prime},+926$ to +907 ) were chosen to bridge the intron of PAR-2, and to amplify a 921-bp fragment. The PCR amplification used $1.5 \mu \mathrm{g}$ RNA according to the manufacturer's directions. PCR products were separated on a $1 \%$ agarose gel, transferred to a nylon membrane, cross-linked, and analyzed by Southern blotting using a probe labeled with digoxigenin-11-dUTP according to the manufacturer's directions (Boehringer Mannheim, Mannheim, Germany). A 162-bp digoxigenin-labeled probe was generated by PCR using a vector containing a rat PAR-2 fragment as a template (from Dr. Morley Hollenberg) and oligonucleotide primers to rat PAR-2 (sense, 5'-TGCTGGGAGGTATCACCCTT-3', +26 to +45; antisense, 5'-CATCAACGGAAAAGCCTGGT-3', +187 to +168). The probe was purified using Chroma Spin X-100 columns (Clontech, Palo Alto, CA). Membranes were prehybridized in $5 \times$ SSPE, $10 \times$ Denhardt's, $50 \%$ deionized formamide, $100 \mathrm{mg} / \mathrm{ml}$ salmon sperm DNA, and $2 \%$ SDS for $3 \mathrm{~h}$ at $42^{\circ} \mathrm{C}$, and hybridized with probe overnight at $42^{\circ} \mathrm{C}$. They were washed $40 \mathrm{~min}$ at room temperature in $2 \times$ SSC with $0.05 \%$ SDS, and $20 \mathrm{~min}$ at $55^{\circ} \mathrm{C}$ in $0.1 \times$ SSC with $0.1 \%$ SDS. Membranes were incubated with anti-digoxigenin antibody coupled to alkaline phosphatase (Boehringer Mannheim) and developed with BCIP/NBT substrate.

$\mathrm{Ca}^{2+}$ mobilization. Myocytes were incubated in physiological salt solution with $2.5 \mu \mathrm{M}$ Fura-2/AM for $20 \mathrm{~min}$ at $37^{\circ} \mathrm{C}$ (28). Fluorescence was measured in individual cells using an ICCD video camera (Stanford Photonics, Stanford, CA) and a video microscopy acquisition program (Axon Industries, Foster City, CA.). Fluorescence was measured at 340 and $380 \mathrm{~nm}$ excitation and $510 \mathrm{~nm}$ emission. The ratio of the fluorescence at the two excitation wavelengths, which is proportional to the $\left[\mathrm{Ca}^{2+}\right]_{\mathrm{i}}$, was calculated. Fresh cells were studied with each agonist, and a minimum of 10 cells were analyzed in 2-4 experiments on different days.

Contraction of muscle strips. Strips (1-cm long) of rat proximal colon were suspended in an organ bath containing $3 \mathrm{ml}$ of KrebsRinger-Bicarbonate gassed with $95 \% \mathrm{O}_{2} / 5 \% \mathrm{CO}_{2}$ at $37^{\circ} \mathrm{C}$ to record longitudinal contractions. Isometric contractions were recorded and analyzed using AcqKnowledge 3.1 (BioPac, Santa Barbara, CA). A basal tension of $1 \mathrm{~g}$ was applied to achieve maximal reproducible spontaneous activity. Tissues were equilibrated for $1 \mathrm{~h}$. The mean amplitude of contraction was determined for 5 min before and after administration of agonists. Data are representative of experiments with at least four colon strips from at least three different animals.

Degranulation of mast cells. HMC-1 human mast cells $(300 \mu \mathrm{l}$ of $7 \times 10^{6}$ cells $/ \mathrm{ml}$ in physiological salt solution containing $25 \mu \mathrm{g} / \mathrm{ml}$ heparin) were incubated with $100 \mu \mathrm{M}$ substance $P$ for $5 \mathrm{~min}$ at room temperature to induce degranulation. The suspension was filtered, diluted, and assayed for stimulation of $\mathrm{Ca}^{2+}$ mobilization. Tryptase release was maximal under these conditions.

\section{Results}

Localization of PAR-2 in the colon. We localized PAR-2 in sections of rat colon and in cultured myocytes using antisera to different epitopes, and obtained similar results with each antiserum. Immunoreactive PAR-2 was prominently localized to the plasma membrane of muscle cells in the circular and longi-

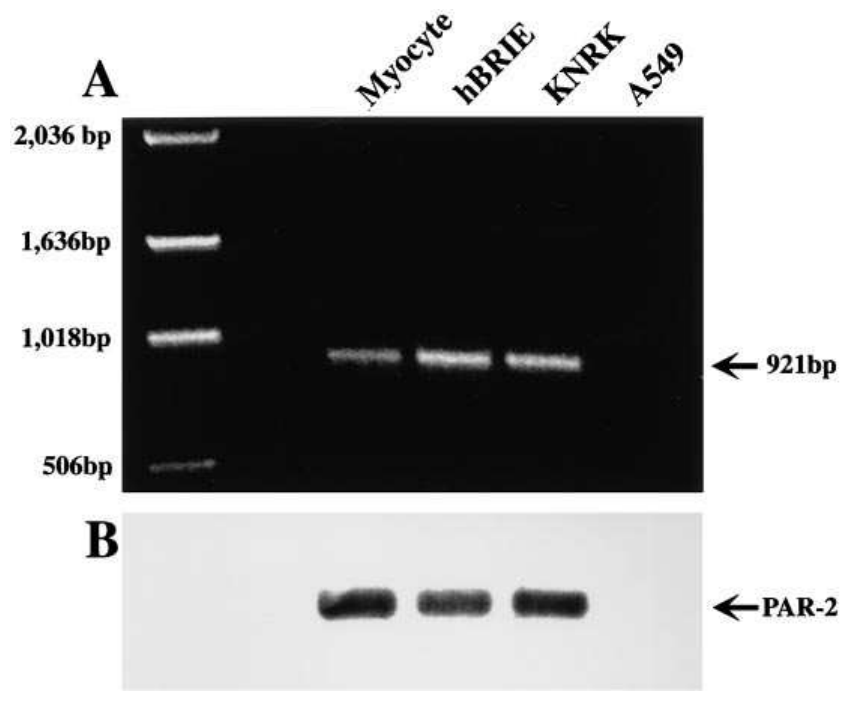

Figure 2. Expression of PAR-2 by colonic myocytes. $A$ shows the amplification by RT-PCR of a product of the predicted $921 \mathrm{bp}$ from RNA prepared from cells expressing rat PAR-2 (colonic myocytes, hBRIE 380 cells, KNRK cells) but not human PAR-2 (A549 cells). $B$ is a Southern blot showing that the products hybridize with a probe to rat PAR-2.

tudinal muscle and the muscularis mucosa (Fig. $1 A$ ). PAR-2 was also detected in colonocytes, especially in the apical regions of cells (not shown). Cultured myocytes stained for smooth muscle actin, and thus retained their smooth muscle characteristics (Fig. $1 \mathrm{~B}$ ). PAR-2 was detected at the plasma membrane and in vesicles of cultured myocytes (Fig. $1 C$ ). Staining of tissues and cells was abolished by preabsorption of the primary antisera with $1-10 \mu \mathrm{M}$ of the receptor fragments used for immunization (Fig. $1 D$ ).

Expression of PAR-2 in colon myocytes. We examined the expression of PAR-2 mRNA in cultured myocytes by RT-PCR using primers to rat PAR-2. We also used two rat cell lines (KNRK and hBRIE 380 cells) as positive controls that are known to express PAR-2, and one human cell line (A549) as a negative control that also expresses PAR-2 (6). A PCR product of the predicted 921 bp was amplified using RNA from myocytes, KNRK cells, and hBRIE 380 cells, but not from A549 cells (Fig. 2 A). Amplification products from myocytes, KNRK cells, and hBRIE 380 cells hybridized with a probe to rat PAR-2, confirming the identity of the amplified fragment as PAR-2 (Fig. $2 B$ ).

$\mathrm{Ca}^{2+}$ mobilization by colonic myocytes. We assessed the activation of PAR-2 in myocytes by measuring $\mathrm{Ca}^{2+}$ mobilization. Trypsin and AP stimulated a prompt increase in $\left[\mathrm{Ca}^{2+}\right]_{i}$ (Fig. 3). Trypsin $\left(\mathrm{EC}_{50}, \sim 1 \mathrm{nM}\right)$ was 1,000 -fold more potent than $\mathrm{AP}\left(\mathrm{EC}_{50}, \sim 1 \mu \mathrm{M}\right)$, although trypsin and $\mathrm{AP}$ had the same efficacy (Fig. 4). There was no $\mathrm{Ca}^{2+}$ response to $1 \mathrm{nM}$ trypsin that was preincubated with $10 \mathrm{mg} / \mathrm{ml} \mathrm{SBTI}$ for $60 \mathrm{~min}$ at $37^{\circ} \mathrm{C}$ before assay, and RP had no effect on $\left[\mathrm{Ca}^{2+}\right]_{i}$ (Fig. 3).

Tryptase stimulated an increase in $\left[\mathrm{Ca}^{2+}\right]_{\mathrm{i}}$ in myocytes (Figs. 5 and 6). In contrast to trypsin and AP, which induced an almost immediate increase in $\left[\mathrm{Ca}^{2+}\right]_{i}$ in all cells, tryptase stimulated $\mathrm{Ca}^{2+}$ mobilization after a delay of 10-30 s (Fig. 6). Tryptase $\left(\mathrm{EC}_{50}, \sim 100 \mathrm{nM}\right)$ was 100 -fold less potent than trypsin $\left(\mathrm{EC}_{50}, \sim 1 \mathrm{nM}\right)$, but was similarly efficacious (Fig. 4). There was no $\mathrm{Ca}^{2+}$ response to $40 \mathrm{nM}$ tryptase that was prein- 

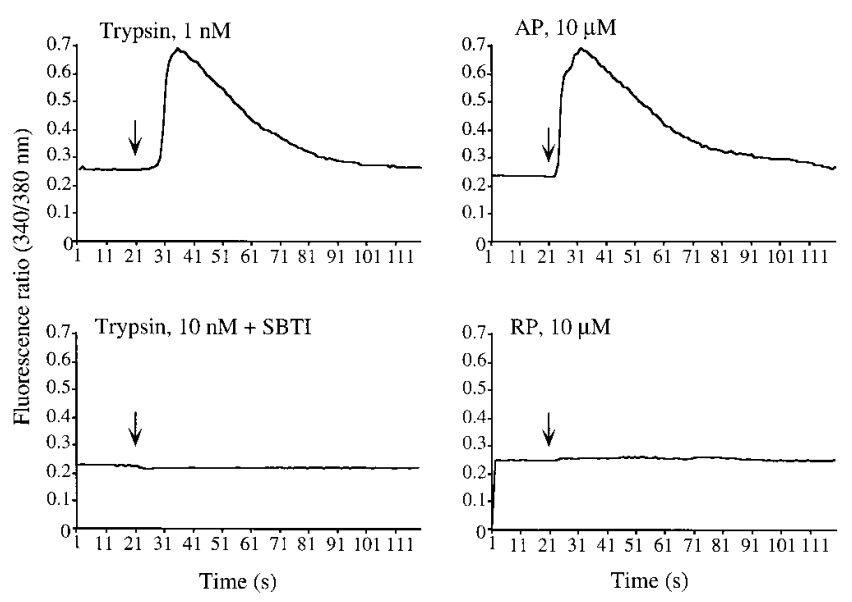

Figure 3. Effects of trypsin (left) and AP and RP (right) on $\left[\mathrm{Ca}^{2+}\right]_{\mathrm{i}}$ in colonic myocytes. Results are from individual cells, and are representative of observations $>10$ cells.

cubated with $1 \mu \mathrm{M}$ of BABIM, a selective and potent tryptase inhibitor (25), or with $1 \mu \mathrm{M}$ leupeptin, a serine protease inhibitor, for $5 \mathrm{~min}$ at room temperature before assay. Thus, the effect of tryptase depends on its enzymatic activity.

We induced degranulation of HMC-1 cells with substance $\mathrm{P}$ and assayed a filtrate for $\mathrm{Ca}^{2+}$ responses in myocytes, to determine if mast cells release proteases that cleave and activate PAR-2. Application of HMC-1 mast cell filtrate (10 $\mu$ l of a 1:500 dilution, i.e., $0.02 \mu$ l filtrate) to myocytes (1-ml assay volume) stimulated a rapid and large increase in $\left[\mathrm{Ca}^{2+}\right]_{\mathrm{i}}$ in myocytes (Figs. 5 and 6 ). The response was inhibited by $46.5 \pm 1 \%$ by BABIM, and $46.5 \pm 4 \%$ by leupeptin, and is thus dependent to a large extent on tryptase. We examined whether substance $\mathrm{P}$

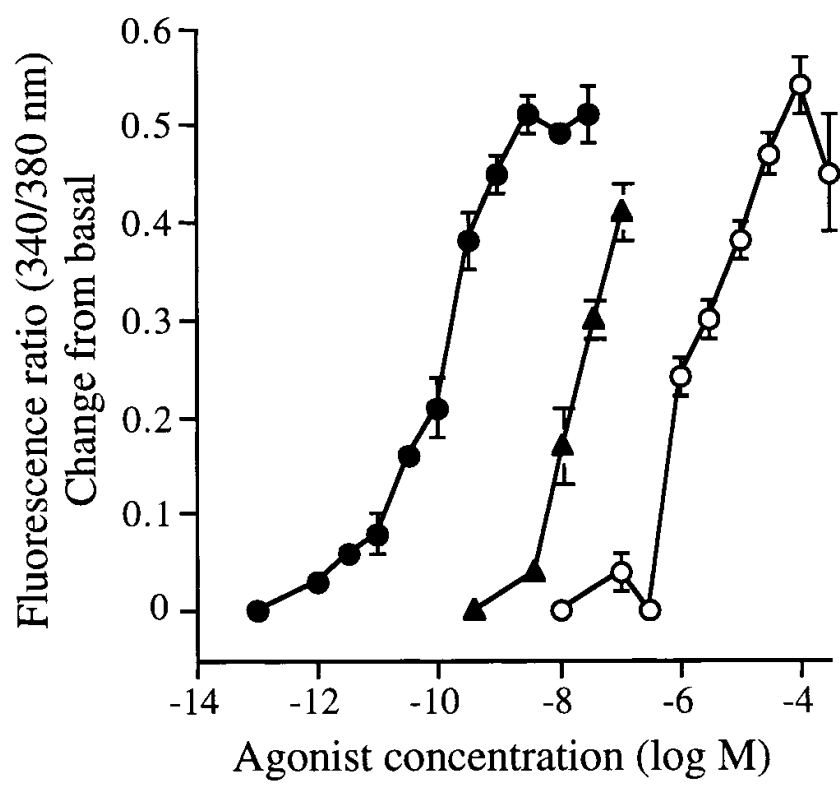

Figure 4. Effects of graded concentrations of trypsin, purified HMC- 1 tryptase, and AP on $\left[\mathrm{Ca}^{2+}\right]_{i}$ in myocytes. Results are expressed as change from basal and are mean $\pm \mathrm{SE}$ of observations of $>10$ cells. Filled circles, trypsin; filled triangles, HMC-1 Tryptase; open circles, AP. could induce $\mathrm{Ca}^{2+}$ mobilization in myocytes. Since the filtrate (containing $100 \mu \mathrm{M}$ substance P) was diluted before assay, the final concentration of substance $P$ to which myocytes were exposed was only $2 \mathrm{nM}$. Even very high concentrations of substance $\mathrm{P}(100 \mu \mathrm{M})$, however, did not stimulate $\mathrm{Ca}^{2+}$ mobilization in myocytes (Fig. 6).

Desensitization of $\mathrm{Ca}^{2+}$ mobilization. Exposure of cells to trypsin desensitizes $\mathrm{Ca}^{2+}$ responses to subsequent challenges with trypsin and AP due to cleavage of PAR-2 and uncoupling of the receptor from signaling mechanisms (29). We examined desensitization of $\mathrm{Ca}^{2+}$ responses by trypsin to verify that tryptase stimulates $\mathrm{Ca}^{2+}$ mobilization in myocytes by cleaving and activating PAR-2. Exposure of myocytes to $1 \mathrm{nM}$ trypsin for 2 min almost completely desensitized the $\mathrm{Ca}^{2+}$ response to a second challenge with $1 \mathrm{nM}$ trypsin or $40 \mathrm{nM}$ tryptase (Fig. 7, Table I). This suggests that trypsin and tryptase induce $\mathrm{Ca}^{2+}$ mobilization by cleaving and activating the same receptor on myocytes. Exposure of myocytes to $40 \mathrm{nM}$ tryptase for $2 \mathrm{~min}$ partially desensitized the $\mathrm{Ca}^{2+}$ response to a second challenge with $40 \mathrm{nM}$ tryptase or $1 \mathrm{nM}$ trypsin (Fig. 7, Table I). This diminished desensitization by tryptase compared to trypsin may reflect the reduced effectiveness with which tryptase cleaves and activates PAR-2. Bradykinin $(1 \mu \mathrm{M})$ stimulated an increase in $\left[\mathrm{Ca}^{2+}\right]_{i}$ in myocytes after trypsin and tryptase, indicating that depletion of the intracellular $\mathrm{Ca}^{2+}$ pools is not the mechanism of desensitization.

Effects of PAR-2 agonists on colonic motility. Our results indicate that colonic muscle expresses PAR-2, and that trypsin, AP, and tryptase activate PAR-2 on myocytes. We examined the functional consequences of PAR-2 activation by measur-
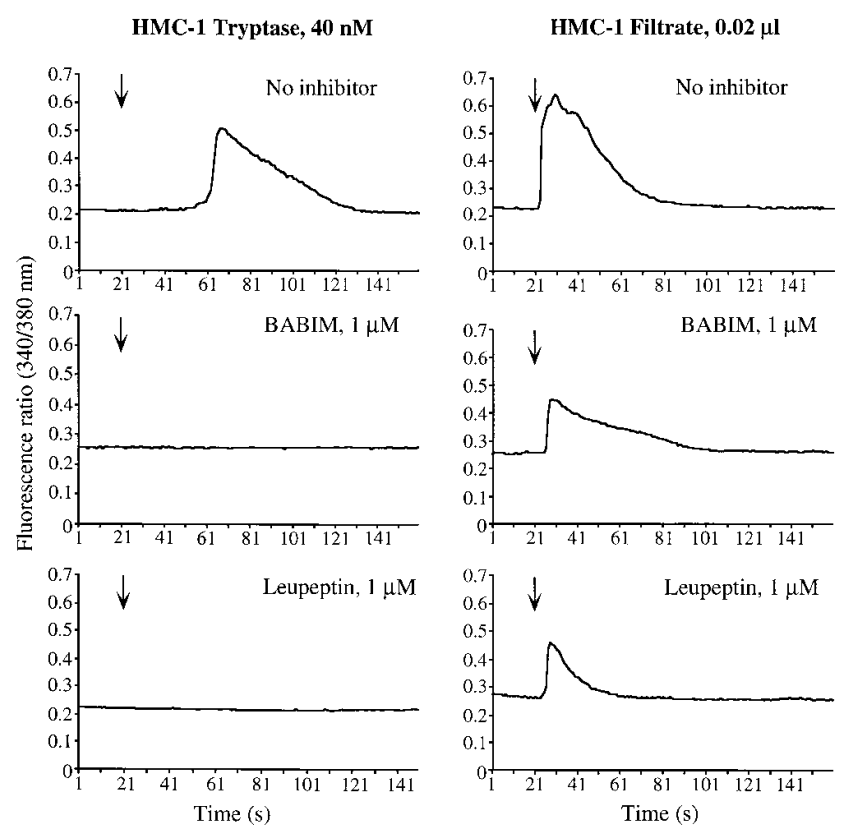

Figure 5. Effects of tryptase (left) and of a filtrate of degranulated HMC- 1 cells $(r i g h t)$ on $\left[\mathrm{Ca}^{2+}\right]_{\mathrm{i}}$ in colonic myocytes. The HMC-1 filtrate was obtained as described in Methods, and $10 \mu \mathrm{l}$ of a 500 -fold dilution of filtrate $(0.02 \mu \mathrm{l}$ filtrate $)$ was assayed in a volume of $1 \mathrm{ml}$. BABIM and leupeptin were incubated with tryptase or HMC-1 filtrate for $5 \mathrm{~min}$ at room temperature before assay. Results are from individual cells, and are representative of observations of $>10$ cells. 

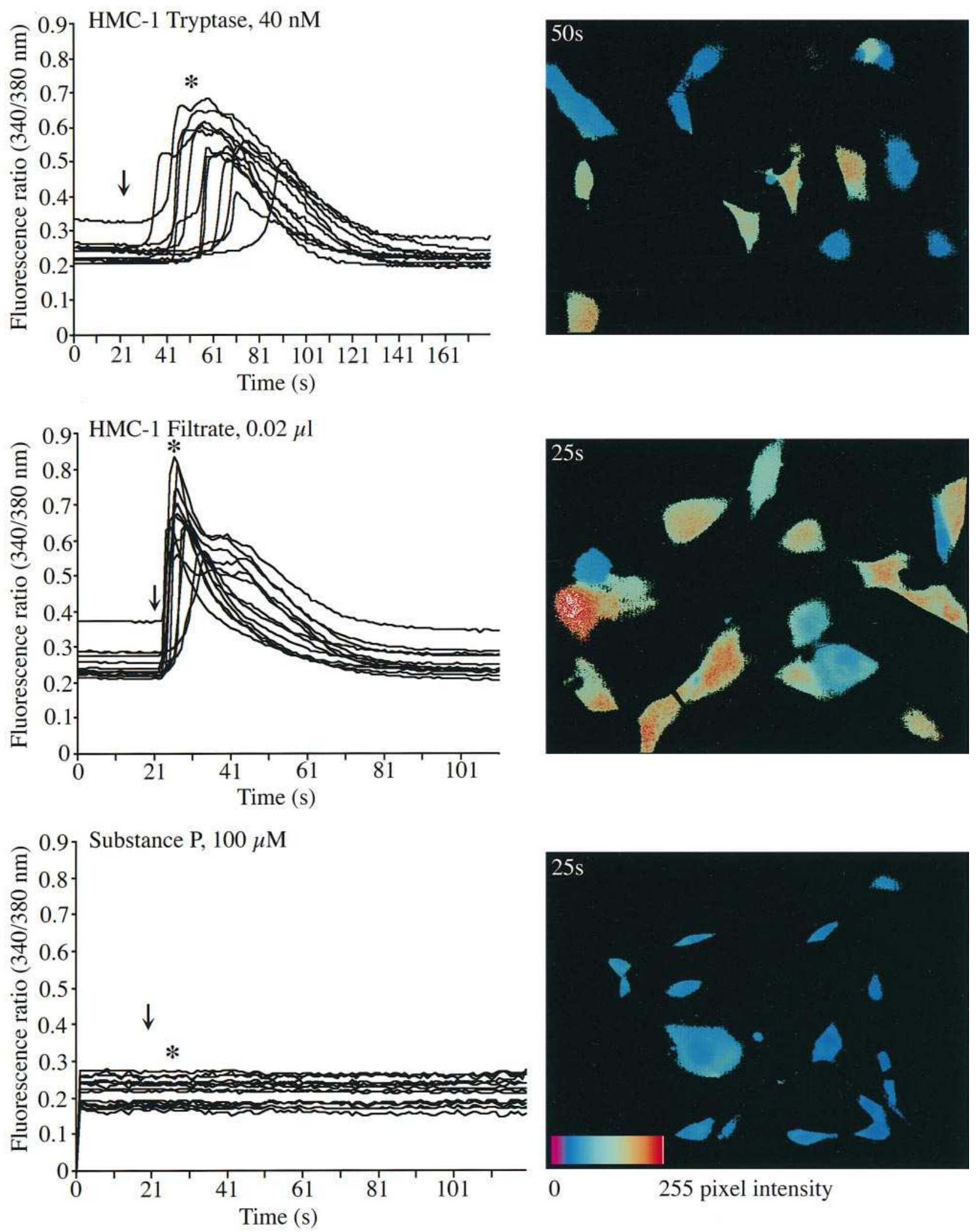

Figure 6. Effects of tryptase, a filtrate of HMC-1 cells, and substance $\mathrm{P}$ on $\left[\mathrm{Ca}^{2+}\right]_{\mathrm{i}}$ in colonic myocytes. The left panels show the time course of results from individual myocytes. The right panels show pseudocolor images of the same cells as those in the left panels. *Indicates the time at which these images were taken. HMC-1 cells were degranulated as described in Methods. 

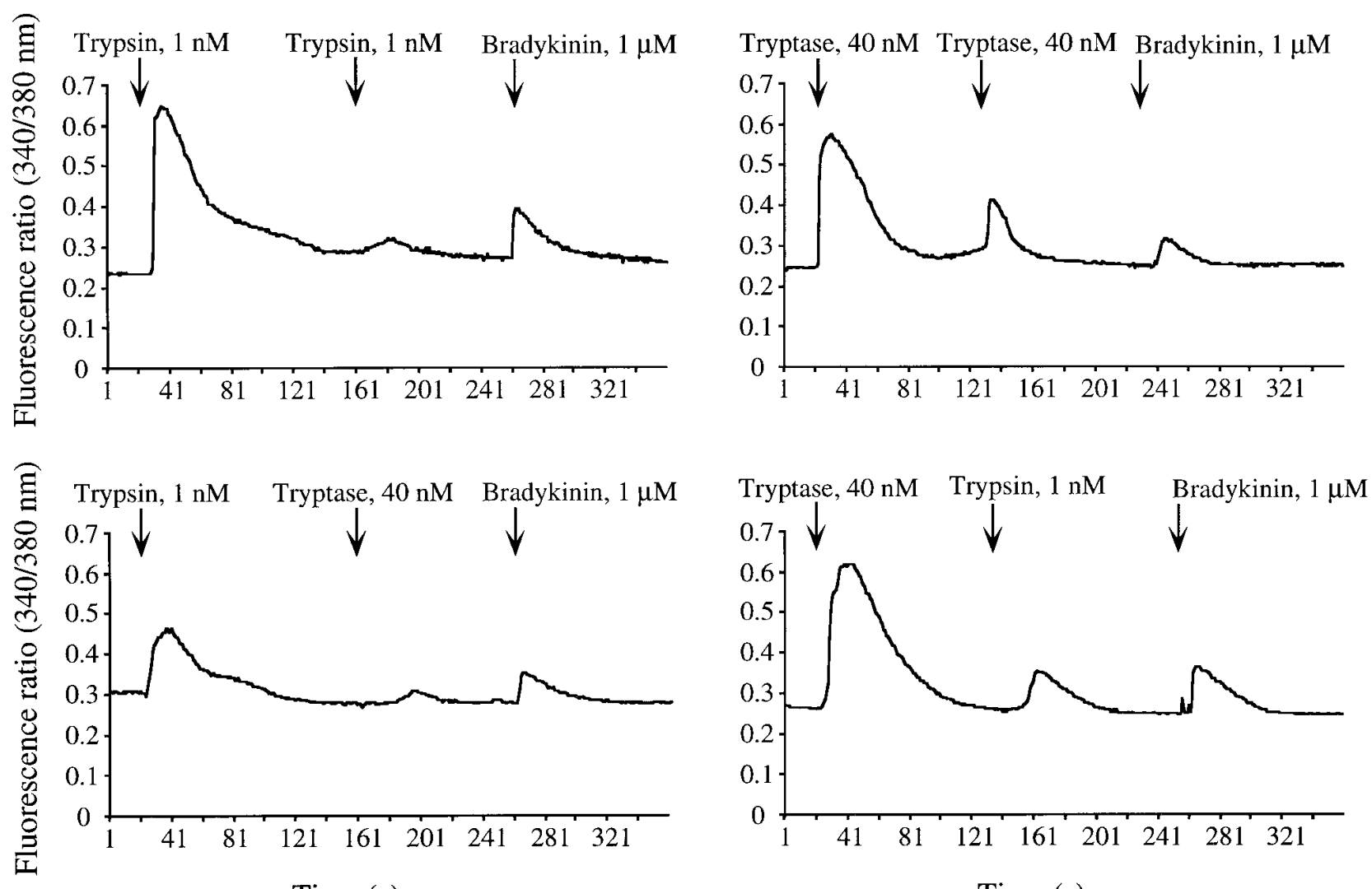

Time (s)

Time (s)

Figure 7. Effects of desensitization of PAR-2 with trypsin (left) or tryptase (right) on $\mathrm{Ca}^{2+}$ responses to trypsin and tryptase in myocytes. Cells were exposed to $1 \mathrm{nM}$ trypsin or $40 \mathrm{nM}$ tryptase for $2 \mathrm{~min}$, and were then challenged again with $1 \mathrm{nM}$ trypsin or $40 \mathrm{nM}$ tryptase. 2 min later they were exposed to $1 \mu \mathrm{M}$ bradykinin. Cells were not washed between challenges. Results are from individual cells, and are representative of observations of $>10$ cells in $2-4$ experiments.

ing contraction of muscle strips. $92 \%$ of colon strips (mucosa plus muscle) were spontaneously active. The frequency of contraction was $3.7 \pm 0.15 / \mathrm{min}$, the mean amplitude was $1.8 \pm 0.2 \mathrm{~g}$, and the maximal amplitude was $2.5 \mathrm{~g}$. Activation of PAR-2 with trypsin and AP caused a concentration-dependent reduction in the mean amplitude of spontaneous contractions (Figs. 8 and 9). The threshold for inhibition was $300 \mathrm{nM}$ for trypsin and $3 \mu \mathrm{M}$ for AP. Trypsin $\left(\mathrm{EC}_{50}, \sim 500 \mathrm{nM}\right)$ was 10 -fold more potent than $\mathrm{AP}\left(\mathrm{EC}_{50}, \sim 5 \mu \mathrm{M}\right)$. The highest concentration of trypsin $(3 \mu \mathrm{M})$ inhibited the mean amplitude by $60 \%$, and the highest concentration of AP $(30 \mu \mathrm{M})$ inhibited the mean amplitude by $49 \%$, indicating that trypsin is slightly more efficacious than AP. Trypsin $(1 \mu \mathrm{M})$ inhibited contraction after a delay of $31 \pm 5 \mathrm{~s}$, whereas inhibition by AP occurred after a delay of $15 \pm 3 \mathrm{~s}$. When tissues were exposed to $1 \mu \mathrm{M}$ trypsin or $100 \mathrm{nM}$ AP for $5 \mathrm{~min}$, and then washed extensively, spontaneous activity did not fully recover to basal levels even $6 \mathrm{~h}$ after trypsin, whereas activity recovered $5.4 \pm 0.34 \mathrm{~min}$ after AP.

Table I. Desensitization of the $\mathrm{Ca}^{2+}$ Response of Colonic Myocytes

\begin{tabular}{lllc}
\hline \multicolumn{1}{c}{ First agonist } & Response & Second agonist & Desponse \\
\hline & & & \\
Trypsin $(1 \mathrm{nM})$ & $0.30 \pm 0.02$ & Trypsin $(1 \mathrm{nM})$ & $0.03 \pm 0.001 *$ \\
Trypsin $(1 \mathrm{nM})$ & $0.30 \pm 0.02$ & Tryptase $(40 \mathrm{nM})$ & $0.02 \pm 0.001 *$ \\
Tryptase $(40 \mathrm{nM})$ & $0.33 \pm 0.02$ & Trypsin $(1 \mathrm{nM})$ & $0.07 \pm 0.01 *$ \\
Tryptase $(40 \mathrm{nM})$ & $0.33 \pm 0.02$ & Tryptase $(40 \mathrm{nM})$ & 93 \\
& & & 77 \\
\end{tabular}

Myocytes were challenged with trypsin or tryptase (first agonist), and then challenged with the same dose of protease (second agonist) 2 min later

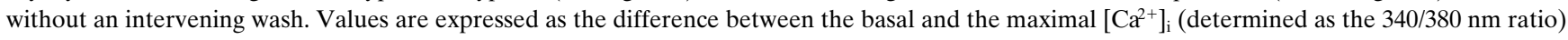
and are the mean \pm SE of observations of $>10$ cells. Desensitization of the response to the second agonist challenge is expressed as a percentage of the response to the first challenge with the same agonist. $* P<0.05$ for cells exposed to the second agonist compared to cells exposed to the same first agonist (Student's $t$ test). 


\section{Trypsin}
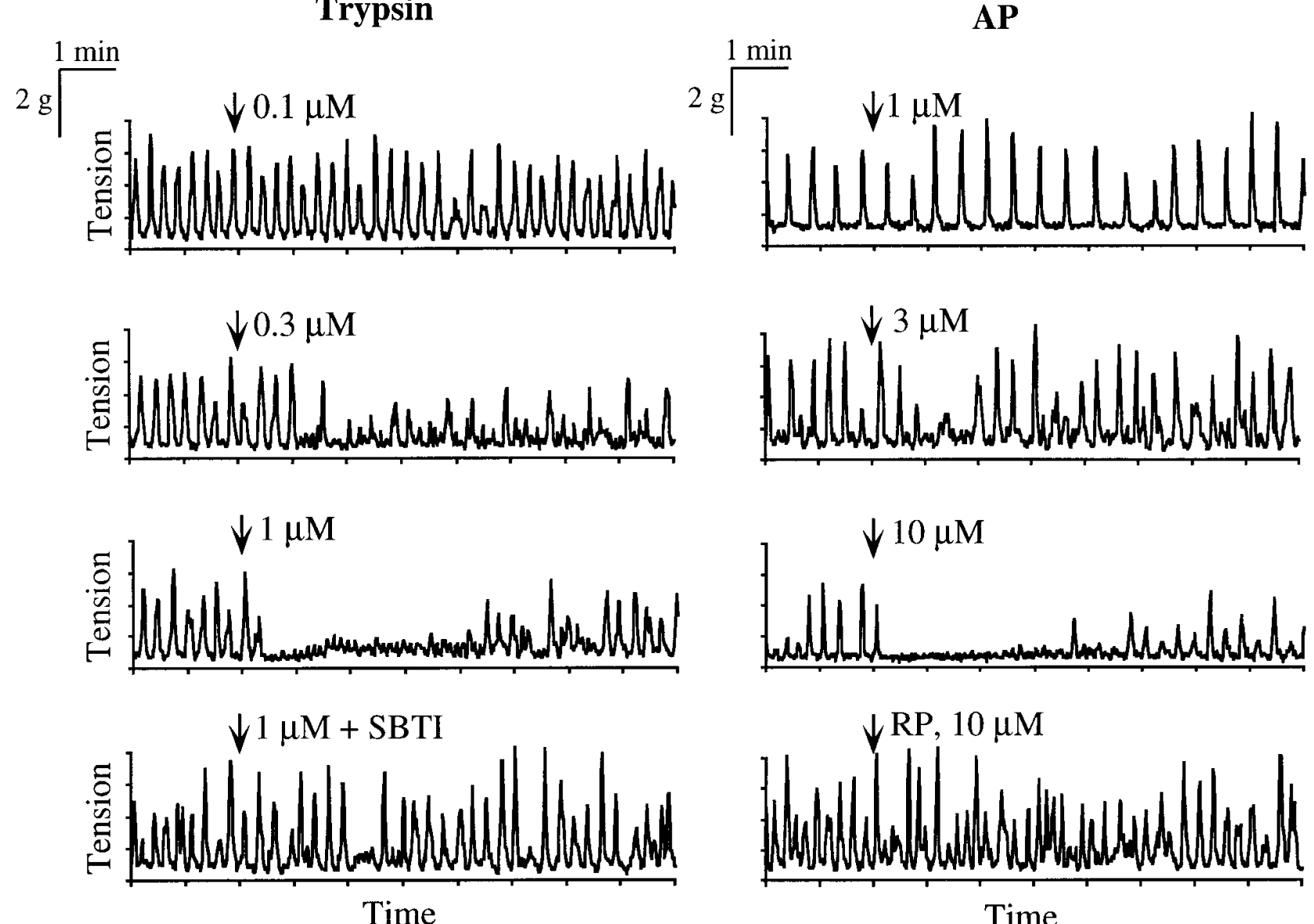

Time

Figure 8. Effects of trypsin (left) and AP (right) on spontaneous contraction of strips of rat colon. The traces are from individual strips, but are representative of experiments on strips from at least four rats.

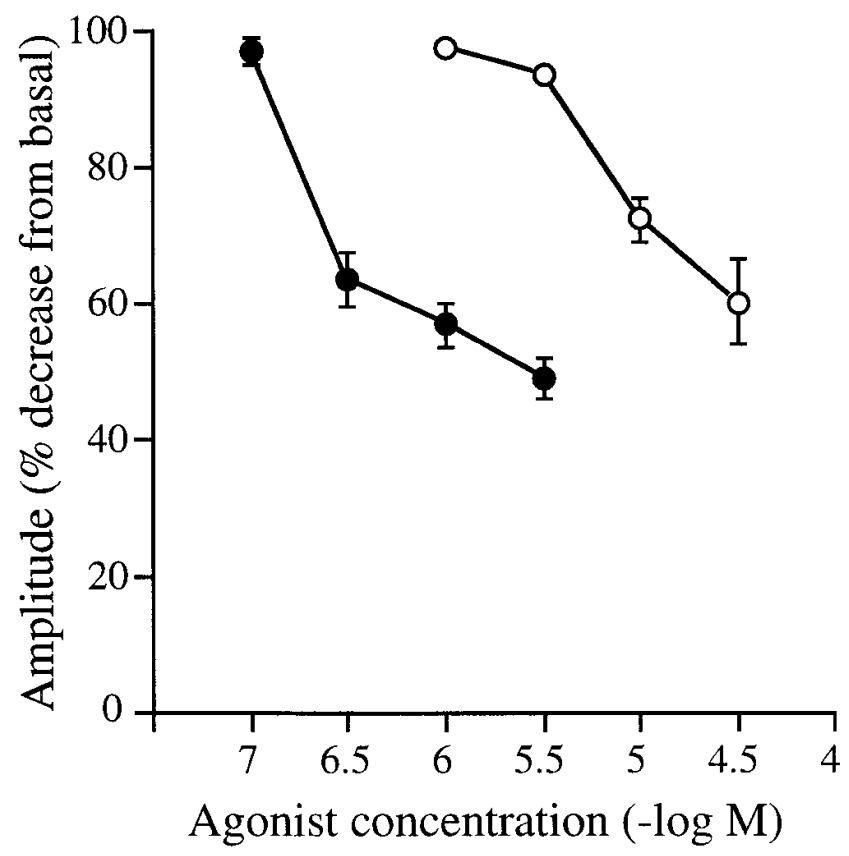

Figure 9. Effects of graded concentrations of trypsin and AP on the mean amplitude of spontaneous contractions of strips of rat colon.
The reason for the prolonged inhibition of motility by trypsin is unknown, although it could be related to cleavage of other receptors that mediate spontaneous colonic contractions. Application of tryptase to the organ bath at concentrations of up to $90 \mathrm{nM}$ did not alter the amplitude of spontaneous contractions. The reason for the lack of inhibition by tryptase is not known, but may be related to its slow rate of diffusion in tissues (30) and difficulties in obtaining sufficiently large amounts of tryptase.

We used agonists and antagonists of various signaling pathways, at concentrations known to be effective in other systems, to investigate the mechanism by which PAR-2 activation inhibited spontaneous contractions of the colon. Activation of PAR-2 stimulates arachidonic acid release and secretion of $\mathrm{PGE}_{2}$ from enterocytes (13), and the effects of PAR-2 agonists on gastric muscle are blocked with indomethacin (11). Although $30 \mathrm{nM} \mathrm{PGE}_{2}$ (31) inhibited colonic motility, preincubation of tissues with $1 \mu \mathrm{M}$ indomethacin (cyclooxygenase inhibitor, [11]) for $15 \mathrm{~min}$ had no effect on the response to trypsin

Results are mean \pm SE of observations of colon strips from at least four rats. Responses are expressed as a percent reduction from baseline mean amplitude (100\%). Filled circles, trypsin; open circles, AP. 

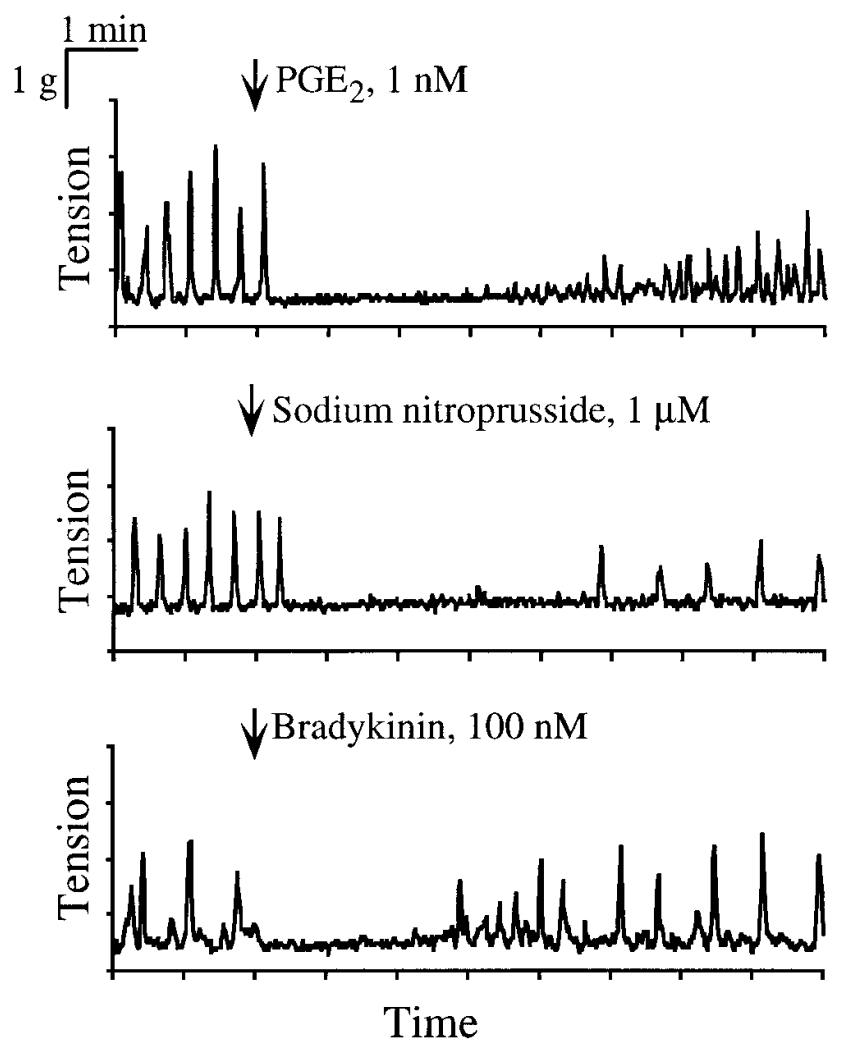
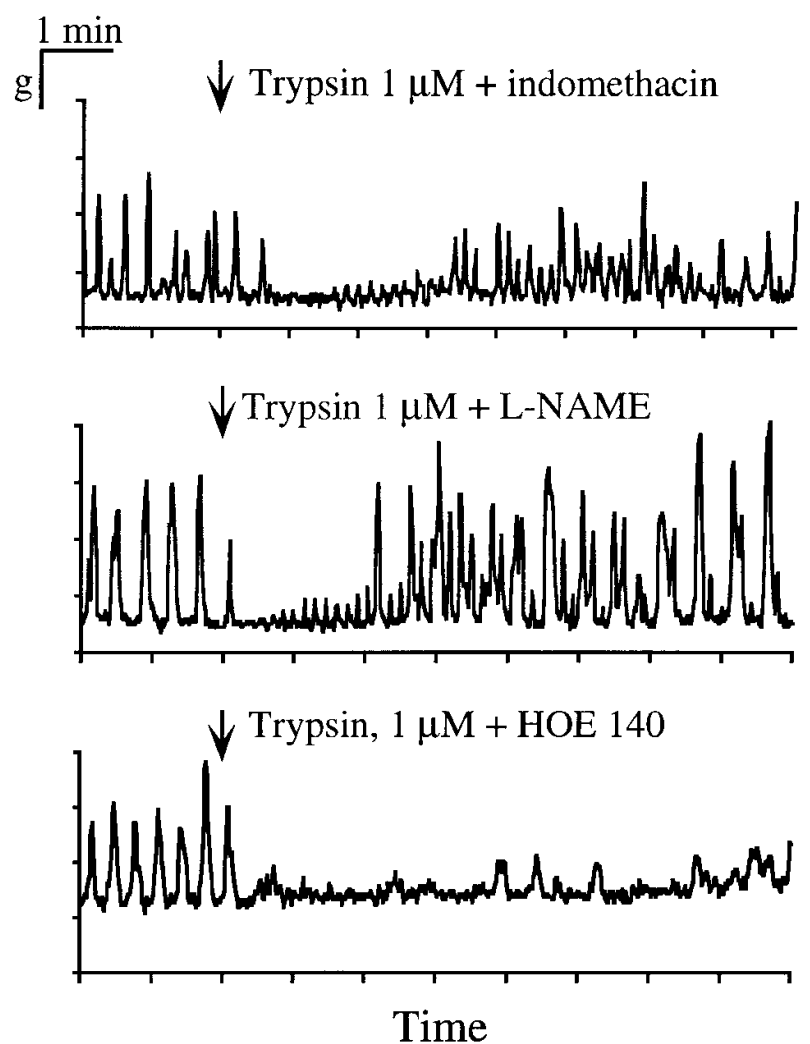

Figure 10. The left panels show the effects of $\mathrm{PGE}_{2}$, sodium nitroprusside, and bradykinin on spontaneous contractions of strips of rat colon. The right panels show the effects of trypsin on spontaneous contractions of strips of rat colon treated with indomethacin, L-NAME, and HOE 140. The traces are from individual strips, but are representative of experiments on strips from at least four rats.

and AP (Fig. 10, Table II). Nitric oxide, which is generated in neurons and muscle cells in the intestine, is an established inhibitor of colonic motility (32), and the inhibitory effects of PAR-2 agonists on contraction of vascular smooth muscle is mediated by nitric oxide from the endothelium (11). Although $1 \mu \mathrm{M}$ sodium nitroprusside (nitric oxide donor, [33]) inhibited colonic motility, preincubation of tissues with $100 \mu \mathrm{M}$ L-NAME (L- $N^{\mathrm{G}}$-nitro arginine methyl ester, inhibitor of nitric oxide synthase, [34]) for $15 \mathrm{~min}$, did not prevent the effects of trypsin and AP (Fig. 10, Table II). Trypsin may cleave tissue kininogens to generate kinins, which could inhibit colonic motility. When colonic strips were exposed to $100 \mathrm{nM}$ bradykinin, there was a marked inhibition of spontaneous contractions that was abolished by preincubation with $100 \mathrm{nM}$ HOE-140 ( $\mathrm{B}_{2}$ receptor antagonist, [35]) for $5 \mathrm{~min}$ (Fig. 10, Table II). HOE-140, however, had no effect on the inhibition of colonic motility by trypsin and AP.

We treated colonic strips with tetrodotoxin (blocks neuronal $\mathrm{Na}^{+}$channels) to assess the role of neurotransmission in the inhibitory effects of PAR-2 agonists. Treatment with $1 \mu \mathrm{M}$ tetrodotoxin (36) resulted in an immediate and sustained increase in the amplitude and frequency of contractions (Fig. 11). Both trypsin and AP, however, inhibited this elevated motility of tetrodotoxin-treated tissues.

Table II. Effects of Agonists and Antagonists on the Mean Amplitude of Spontaneous Contractions of Strips of Rat Colon

\begin{tabular}{|c|c|c|c|c|c|c|c|c|}
\hline Agonist & $\mathrm{PGE}_{2}(30 \mathrm{nM})$ & $\begin{array}{l}\text { Na nitroprusside } \\
\qquad(1 \mu \mathrm{M})\end{array}$ & $\begin{array}{l}\text { Bradykinin } \\
(100 \mathrm{nM})\end{array}$ & $\begin{array}{l}\text { Bradykinin } \\
(100 \mathrm{nM})\end{array}$ & \multicolumn{4}{|c|}{ Trypsin $(1 \mu \mathrm{M})$} \\
\hline Antagonist & None & None & None & $\begin{array}{l}\text { HOE-140 } \\
\quad(100 \mathrm{nM})\end{array}$ & None & $\begin{array}{l}\text { Indomethacin } \\
\qquad(1 \mu \mathrm{M})\end{array}$ & $\begin{array}{l}\text { L-NAME } \\
\qquad(100 \mu \mathrm{M})\end{array}$ & $\begin{array}{l}\text { HOE-140 } \\
\qquad(100 \mathrm{nM})\end{array}$ \\
\hline $\begin{array}{l}\text { Mean amplitude (\% decrease } \\
\text { from basal }[100 \%])\end{array}$ & $55.3 \pm 4.0$ & $62.5 \pm 2.9$ & $25.0 \pm 1.3$ & $2.4 \pm 1.3$ & $56.6 \pm 3.2$ & $64.5 \pm 12.6$ & $57.9 \pm 2.1$ & $45.5 \pm 11.5$ \\
\hline
\end{tabular}

Results are mean $\pm \mathrm{SE}$ of observations of colon strips from at least three rats. Responses are expressed as a percent reduction from baseline mean amplitude $(100 \%)$. Exposure of tissues to $\mathrm{PGE}_{2}$, sodium nitroprusside, bradykinin, and trypsin reduced the mean amplitude of contractions. The response to bradykinin was abolished by preincubation of tissues with HOE-140. Preincubation of tissue with indomethacin, L-NAME, or HOE-140 had no effect on the response to trypsin. 

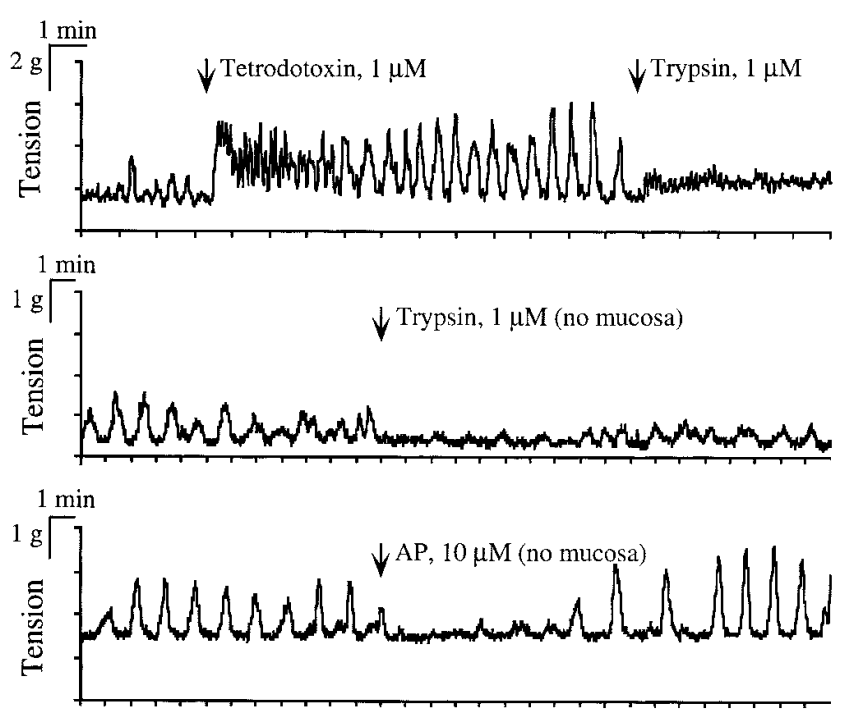

Time

Figure 11. The upper panel shows the effects of trypsin on spontaneous contractions of a strip of rat colon that has been treated with tetrodotoxin. The middle and lower panels show the effects of trypsin and AP on spontaneous contractions of strips of rat colon from which the mucosa has been removed. The traces are from individual strips, but are representative of experiments on strips from at least four rats.

To determine if the effects of PAR-2 agonists on colonic motility were due to release of mediators from the mucosa, we examined their effects on colonic strips from which the mucosa had been removed by dissection. Removal of the mucosa diminished the spontaneous activity of the colon, so that only $65 \%$ of muscle strips were spontaneously active (Fig. 11). The frequency of contraction of spontaneously active strips was $1.5 \pm 0.2 / \mathrm{min}$, the mean amplitude was $1.2 \pm 0.2 \mathrm{~g}$, and the maximal amplitude was $2.3 \mathrm{~g}$. Both trypsin and AP, however, inhibited spontaneous contractions of colonic strips in the absence of the mucosa.

\section{Discussion}

PAR-2 is highly expressed by colonic smooth muscle, and trypsin and mast cell tryptase activate PAR-2 on myocytes. Activation of PAR-2 by trypsin and a peptide corresponding to the tethered ligand inhibits spontaneous contractions of colonic muscle. Thus, tryptase from degranulated mast cells may suppress colonic motility by cleaving and activating PAR-2.

PAR-2 is expressed by myocytes. Several observations indicate that PAR-2 is highly expressed by smooth muscle in the colon. Firstly, immunoreactive PAR was specifically localized to myocytes in tissue sections and in primary culture using antisera raised to different epitopes of PAR-2. Although we cannot exclude the possibility that the antisera crossreact with another protein, the results suggest that PAR-2 is expressed in colonic smooth muscle. Secondly, PAR-2 was detected in myocytes in primary culture using RT-PCR. PAR-2 has similarly been detected in gastric muscle, which supports our results (11). Thirdly, trypsin, tryptase, and AP stimulated $\mathrm{Ca}^{2+}$ mobilization in myocytes, confirming expression of functional PAR-2. PAR-2 couples to generation of inositol(1, 4, 5)tris- phosphate and mobilization of $\mathrm{Ca}^{2+}$ in transfected cell lines and in cells that naturally express PAR-2, which supports our results $(13,29)$. Finally, trypsin and AP inhibited spontaneous contractions of strips of rat colon. This inhibition was still observed after treatment of tissue with tetrodotoxin and removal of the mucosa, suggesting that these agonists affect motility by a direct action on myocytes. Trypsin and AP also affect motility of gastric muscle, although here contraction is stimulated (11).

Trypsin and tryptase activate PAR-2 on myocytes. An important question in our experiments is whether the responses of myocytes to trypsin, tryptase, and AP are mediated by PAR-2 or are caused by activation of a different receptor. The potency with which trypsin stimulated $\mathrm{Ca}^{2+}$ mobilization in myocytes is similar to that in other cell lines (6), which argues that trypsin stimulates myocytes by activating PAR-2. Although trypsin also activates PAR-1, it is considerably less potent than thrombin (37), and other trypsin receptors have not been identified. The effect of trypsin on $\left[\mathrm{Ca}^{2+}\right]_{\mathrm{i}}$ in myocytes was reproduced by a peptide corresponding to the tethered ligand of PAR-2. Although we cannot be sure that AP only activates PAR-2, SLIGRL does not activate PAR-1 (38). Therefore, it is probable that trypsin and AP activate PAR-2 on colonic myocytes.

Mast cell tryptase stimulated $\mathrm{Ca}^{2+}$ mobilization in myocytes with a similar efficacy, but reduced potency compared to trypsin. The $\mathrm{Ca}^{2+}$ response to tryptase in myocytes was abolished by desensitization of PAR-2 with trypsin. Thus, the most straightforward explanation of our results is that tryptase cleaves and activates PAR-2, although tryptase may also activate other receptors. Tryptase also cleaves and activates PAR-2 in transfected cells, keratinocytes, endothelial cells, and enterocytes, but with a reduced potency and efficacy than trypsin (19) (Böhm et al., manuscript submitted for publication). The reduced efficiency with which tryptase cleaves PAR-2 may explain the consistent delay we observed between addition of tryptase and detection of increased $\left[\mathrm{Ca}^{2+}\right]_{\mathrm{i}}$. Trypsin cleaves PAR-2 at SKGR $\downarrow$ SLIGK to expose a tethered ligand (SLIGK) that binds and activates the cleaved receptor. Experiments with synthetic peptides indicate that tryptase prefers the sequence KGR in the P3, P2, and P1 positions, which are identical to the sequence of PAR-2 (39). Indeed, tryptase cleaves synthetic peptides corresponding to the amino terminus of PAR-2 at the same site as trypsin (19).

Our results show that substance $P$ induces degranulation of HMC-1 mast cells and release of tryptase. A filtrate of the degranulated cells stimulated $\mathrm{Ca}^{2+}$ mobilization in myocytes, which was inhibited by $\sim 50 \%$ by the tryptase inhibitor BABIM, and is thus attributable in large part to tryptase. Substance $\mathrm{P}$, which was used to degranulate mast cells, was not responsible for the BABIM-insensitive component, since even high concentrations of substance $\mathrm{P}$ did not stimulate $\mathrm{Ca}^{2+}$ mobilization. This is surprising since the neurokinin- 2 receptor, which is activated by substance $\mathrm{P}$, is expressed by the muscularis externa of the rat colon (27). The lack of responsiveness to substance $\mathrm{P}$ suggests that colonic myocytes lose functional neurokinin receptors in culture. Thus, substance $\mathrm{P}$ does not contribute to the BABIM-insensitive response, and the mediators of this response are unknown. A filtrate of degranulated mast cells also stimulates $\mathrm{Ca}^{2+}$ mobilization in transfected cells expressing PAR-2, but not in nontransfected control cells, which supports our results (Böhm et al., manuscript submitted 
for publication). Thus, tryptase released from mast cells in the colon wall upon degranulation may regulate myocytes in a paracrine manner through PAR-2.

Functional role of PAR-2 in colonic muscle. Activation of PAR-2 by trypsin and AP inhibited spontaneous contraction of the colon, whereas tryptase had no effect. In contrast, tryptase, trypsin, and AP activated PAR- 2 on isolated myocytes, as assessed by measurement of $\left[\mathrm{Ca}^{2+}\right]_{\mathrm{i}}$. The reason for the different effects of tryptase in muscle strips and isolated myocytes is unknown. One possibility is that tryptase, which exists as a high molecular weight tetramer bound to proteoglycans (40), is too large to effectively penetrate tissues from the organ bath and affect colonic motility. The slow diffusion of tryptase is illustrated by the observation that tryptase is not detected in the circulation within 15-30 min of a systemic anaphylactic reaction, and does not reach maximal levels until 1-2 h, whereas histamine, which is highly diffusable, peaks within 5-10 min (30). In addition, we were unable to purify sufficient quantities of tryptase to use concentrations in excess of $90 \mathrm{nM}$ in the organ bath. High concentrations of trypsin were also required to inhibit colonic motility, and the potency with which trypsin inhibited motility was less than that with which it stimulated $\mathrm{Ca}^{2+}$ mobilization. This too may be related to the slow penetration of colon strips by trypsin, and to the production of trypsin inhibitors by intestinal tissues. In contrast, AP, which has a low molecular weight and is probably highly diffusable, had similar potency in both bioassays.

The mechanism by which PAR-2 activation inhibits colonic motility remains to be defined. PAR-2 agonists inhibited contraction of strips of colon after suppression of neurotransmission with tetrodotoxin and after removal of the mucosa, suggesting a direct inhibitory effect of PAR-2 agonists on muscle cells. Contractile responses were unaffected by indomethacin and L-NAME, and do not depend on products of cyclooxygenase or nitric oxide synthase. In contrast, indomethacin blocks the stimulation of gastric motility by PAR-2 agonists (11), and the inhibition of aortic contraction by PAR-2 agonists depends on the release of nitric oxide from the endothelium (11). The signaling pathway responsible for the inhibition of motility that follows activation of PAR-2 remains to be elucidated.

Our results indicate that PAR-2 is highly expressed by colonic muscle and that mast cell tryptase potently activates PAR-2 on isolated myocytes. Although tryptase did not inhibit motility of strips of colon, other PAR-2 agonists strongly inhibited contraction. Thus, it is possible that tryptase released from mast cells within colonic muscle acts in a paracrine manner to inhibit motility. It is also possible, however, that limited diffusion of tryptase within tissues could limit the extent of its effects in vivo.Tryptase may have other effects in the colon that are mediated by PAR-2. Tryptase is mitogenic for epithelial cells, fibroblasts, and smooth muscle cells, and stimulates ICAM expression by epithelial cells (15-18). The receptor that mediates these effects has not been identified, but one candidate is PAR-2. Indeed, PAR-2 agonists stimulate proliferation of endothelial cells (8).

Mast cells are abundant in the normal colon (20), and intestinal manipulation and inflammation are associated with an influx and degranulation of mast cells (21-23). Further experiments are required to determine if activation of PAR-2 by tryptase contributes to disorders of intestinal motility, such as postoperative ileus (41), that accompany mast cell infiltration and degranulation.

\section{Acknowledgments}

We thank Dr. E. Grady for assistance with myocyte isolation and culture, M. Lovett and P. Gamp for technical assistance, and Drs. M. Hollenberg, C. Derian, R. Tidwell, and J. Butterfield for valuable reagents.

This work was supported by NIH grants DK43207, DK39957, NS21710 and HL 24136.

\section{References}

1. Vu, T.K., D.T. Hung, V.I. Wheaton, and S.R. Coughlin. 1991. Molecular cloning of a functional thrombin receptor reveals a novel proteolytic mechanism of receptor activation. Cell. 64:1057-1068.

2. Ishihara, H., A. Connolly, D. Zeng, M. Kahn, Y. Zheng, C. Timmons, T. Tram, and S. Coughlin. 1997. Protease-activated receptor 3 is a second thrombin receptor in humans. Nature (Lond.). 386:502-506.

3. Nystedt, S., K. Emilsson, C. Wahlestedt, and J. Sundelin. 1994. Molecular cloning of a potential proteinase activated receptor [see comments]. Proc. Natl. Acad. Sci. USA. 91:9208-9212.

4. Grand, R.J., A.S. Turnell, and P.W. Grabham. 1996. Cellular consequences of thrombin-receptor activation. Biochem. J. 313:353-368.

5. Nystedt, S., K. Emilsson, A.K. Larsson, B. Strombeck, and J. Sundelin. 1995. Molecular cloning and functional expression of the gene encoding the human proteinase-activated receptor 2. Eur. J. Biochem. 232:84-89.

6. Böhm, S.K., W. Kong, D. Brömme, S.P. Smeekens, D.C. Anderson, A Connolly, M. Kahn, N.A. Nelken, S.R. Coughlin, D.G. Payan, and N.W. Bunnett. 1996. Molecular cloning, expression, and potential functions of the human proteinase-activated receptor-2. Biochem. J. 314:1009-1016.

7. Santulli, R.J., C.K. Derian, A.L. Darrow, K.A. Tomko, A.J. Eckardt, M. Seiberg, R.M. Scarborough, and P. Andrade-Gordon. 1995. Evidence for the presence of a protease-activated receptor distinct from the thrombin receptor in human keratinocytes. Proc. Natl. Acad. Sci. USA. 92:9151-9155.

8. Mirza, H., V. Yatsula, and W.F. Bahou. 1996. The proteinase activated receptor-2 (PAR-2) mediates mitogenic responses in human vascular endothelial cells. J. Clin. Invest. 97:1705-1714.

9. Hwa, J.J., L. Ghibaudi, P. Williams, M. Chintala, R. Zhang, M. Chatterjee, and E. Sybertz. 1996. Evidence for the presence of a proteinase-activated receptor distinct from the thrombin receptor in vascular endothelial cells. Circ. Res. 78:581-588.

10. Al-Ani, B., M. Saifeddine, and M.D. Hollenberg. 1995. Detection of functional receptors for the proteinase-activated-receptor-2-activating polypeptide, SLIGRL-NH $\mathrm{N}_{2}$, in rat vascular and gastric smooth muscle. Can. J. Phys. Pharm. 73:1203-1207.

11. Saifeddine, M., B. Al-Ani, C. Cheng, L. Wang, and M. Hollenberg 1996. Rat proteinase-activated receptor-2 (PAR-2): cDNA sequence and activity of receptor-derived peptides and in gastric and vascular tissue. Br. J. Pharm. 118:521-530.

12. Mari, B., S. Guerin, D.F. Far, J.P. Breitmayer, N. Belhacene, J.F. Peyron, B. Rossi, and P. Auberger. 1996. Thrombin and trypsin-induced $\mathrm{Ca}(2+)$ mobilization in human $\mathrm{T}$ cell lines through interaction with different proteaseactivated receptors. FASEB J. 10:309-316.

13. Kong, W., K. McConalogue, L. Khitin, M. Hollenberg, D. Payan, S. Böhm, and N. Bunnett. 1997. Luminal trypsin may regulate enterocytes through proteinase-activated receptor 2. Proc. Natl. Acad. Sci. USA. 94:8884-8889.

14. Caughey, G.H. 1995. Mast cell chymases and tryptases: phylogeny, family relations, and biogenesis. In Mast Cell Proteases in Immunology and Biology. G.H. Caughey, editor. Marcel Dekker, Inc., New York. 305-329.

15. Cairns, J.A., and A.F. Walls. 1995. Mast Cell Tryptase is a mitogen for epithelial cells. Stimulation of IL-8 production and intracellular adhesion molecule-1 expression. J. Immunol. 156:275-283.

16. Ruoss, S., T. Hartmann, and G. Caughey. 1991. Mast cell tryptase is a mitogen for cultured fibroblasts. J. Clin. Invest. 88:493-499.

17. Brown, J.K., C.L. Tyler, C.A. Jones, S.J. Ruoss, T. Hartmann, and G.H Caughey. 1991. Tryptase, the dominant secretory granular protein in human mast cells, is a potent mitogen for cultured dog tracheal smooth muscle cells. $J$. Clin. Invest. 88:493-499.

18. Hartmann, T., S.J. Ruoss, W.W. Raymond, K. Seuwen, and G.H. Caughey. 1992. Human tryptase as a potent, cell-specific mitogen: role of signaling pathways in synergistic responses. Am. J. Physiol. 262:L528-L534.

19. Molino, M., E.S. Barnathan, R. Numerof, J. Clark, M. Dreyer, A. Cumashi, J. Hoxie, N. Schechter, M. Woolkalis, and L.F. Brass. 1997. Interactions of mast cell tryptase with thrombin receptors and PAR-2. J. Biol. Chem. 272: 4043-4049.

20. Aldenborg, F., and L. Enerback. 1994. The immunohistochemical demonstration of chymase and tryptase in human intestinal mast cells. Histochem. J. 26:587-596.

21. Vermillion, D.L., and S.M. Collins. 1993. The non-specific induction of mastocytosis in rat intestinal muscle. J. Gastrointest. Mot. 5:1-8.

22. Castro, G., and D. Powell. 1994. The physiology of the mucosal immune 
system and immune-mediated responses in the gastrointestinal tract. In Physiology of the Gastrointestinal Tract. L. Johnson, editor. Raven Press, Ltd., New York. 709-750.

23. Perdue, M., and D. McKay. 1994. Integrative immunophysiology in the intestinal mucosa. Am. J. Physiol. 267:G151-G165.

24. Caughey, G., N. Viro, J. Ramachandran, S. Lazarus, D. Borson, and J. Nadel. 1987. Dog mastocytoma tryptase: affinity purification, characterization and amino-terminal sequence. Arch. Biochem. Biophys. 258:555-563.

25. Caughey, G.H., W.W. Raymond, E. Bacci, R.J. Lombardy, and R.R. Tidwell. 1993. Bis(5-amidino-2-benzimidazolyl)methane and related amidines are potent, reversible inhibitors of mast cell tryptases. J. Pharm. Exp. Ther. 264: 676-682.

26. Collins, S., and J. Gardner. 1982. Cholecystokinin-induced contraction of dispersed smooth muscle cells. Am. J. Physiol. 243:G497-G504.

27. Grady, E.F., P. Baluk, S. Böhm, P. Gamp, H. Wong, D.G. Payan, J. Ansel, A.L. Portbury, J.B. Furness, D.M. McDonald, and N.W. Bunnett. 1996. Characterization of antisera specific to NK1, NK2, and NK3 neurokinin receptors and their utilization to localize receptors in the rat gastrointestinal tract. $J$. Neurosci. 16:6975-6986.

28. Garland, A.M., E.F. Grady, M. Lovett, S.R. Vigna, M.M. Frucht, J.E. Krause, and N.W. Bunnett. 1996. Mechanisms of desensitization and resensitization of the G-protein coupled NK-1 and NK-2 receptors. Mol. Pharmacol. 49: 438-446.

29. Böhm, S.K., L.M. Khitin, E.F. Grady, G. Aponte, D.G. Payan, and N.W. Bunnett. 1996. Mechanisms of desensitization and resensitization of proteinaseactivated receptor-2. J. Biol. Chem. 271:22003-22016.

30. Schwartz, L., J. Yunginger, J. Miller, R. Bokhari, and D. Dull. 1989. Time course and appearance and disappearance of human mast cell tryptase in the circulation after anaphylaxis. J. Clin. Invest. 83:1551-1555.

31. Tottrup, A., A. Forman, U. Raundahl, and K.E. Andersson. 1992. Effects of prostanoids and indomethacin on isolated smooth muscle from the human lower oesophagus. Pharmacol. Toxicol. 71:65-74.

32. Whittle, B. 1994. Nitric oxide in gastrointestinal physiology and patho- physiology. In Physiology of the Gastrointestinal Tract. L. Johnson, editor. Raven Press, Ltd., New York. 267-294.

33. Knudsen, M.A., D. Svane, and A. Tottrup. 1992. Action profiles of nitric oxide, $S$-nitroso-L-cysteine, SNP, and NANC responses in opossum lower esophageal sphincter. Am. J. Physiol. 262:G840-G846.

34. Keef, K.D., C. Du, S.M. Ward, B. McGregor, and K.M. Sanders. 1993. Enteric inhibitory neural regulation of human colonic circular muscle: role of nitric oxide. Gastroenterology. 105:1009-1016.

35. Rhaleb, N.E., N. Rouissi, D. Jukic, D. Regoli, S. Henke, G. Breipohl, and J. Knolle. 1992. Pharmacological characterization of a new highly potent B2 receptor antagonist (HOE 140: D-Arg-[Hyp3, Thi5,D-Tic7, Oic8] bradykinin). Eur. J. Pharmacol. 210:115-120.

36. Shuttleworth, C.W., R. Murphy, and J.B. Furness. 1991. Evidence that nitric oxide participates in non-adrenergic inhibitory transmission to intestinal muscle in the guinea-pig. Neurosci. Lett. 130:77-80.

37. Vouret-Craviari, V., D. Grall, J.C. Chambard, U.B. Rasmussen, J. Pouyssegur, and E. Van Obberghen-Schilling. 1995. Post-translational and activation-dependent modifications of the G protein-coupled thrombin receptor. $J$. Biol. Chem. 270:8367-8372.

38. Blackhart, B.D., K. Emilsson, D. Nguyen, W. Teng, A.J. Martelli, S. Nystedt, J. Sundelin, and R.M. Scarborough. 1996. Ligand cross-reactivity within the protease-activated receptor family. J. Biol. Chem. 271:16466-16471.

39. Tanaka, T., B.J. McRae, K. Cho, R. Cook, J.E. Fraki, D.A. Johnson, and J.C. Powers. 1983. Mammlian tissue trypsin-like enzymes. Comparative reactivities of human skin tryptase, human lung tryptase and bovine trypsin with peptide 4-nitroanilides and thioester substrates. J. Biol. Chem. 258:1355213557.

40. Goldstein, S., J. Leong, L. Schwartz, and D. Cooke. 1992. Protease composition of exocytosed human skin mast cell protease-proteoglycan complexes. Tryptase resides in a complex distinct from chymase and carboxypeptidase. $J$. Immunol. 148:2475-2482.

41. Livingston, E.H., and E.P. Passaro. 1990. Postoperative ileus. Dig. Dis. Sci. 35:121-132. 